\title{
Islamic Bank Service Quality and Trust: Study on Islamic Bank in Makassar Indonesia
}

\author{
Irwan Misbach $^{1}$, Surachman ${ }^{2}$, Djumilah Hadiwidjojo ${ }^{2} \&$ Armanu $^{2}$ \\ ${ }^{1}$ Alauddin State Islamic University, South Sulawesi, Indonesia \\ ${ }^{2}$ School of Economic and Business, Brawijaya University, Malang, Indonesia \\ Correspondence: Irwan Misbach, Alauddin State Islamic University, South Sulawesi, Indonesia. Tel: \\ 62-852-9962-4579. E-mail: irwan.misbach@uin-alauddin.ac.id
}

Received: December 19, 2012

doi:10.5539/ijbm.v8n5p48
Accepted: January 23, 2012 Online Published: February 16, 2013

URL: http://dx.doi.org/10.5539/ijbm.v8n5p48

\begin{abstract}
Main theme that is always to be a hot topic for the management of Islamic banking is how to find an appropriate way to expand its market Islamic banking. Current market contribution of Islamic banking is only around 2\% of the total national banking and only 1.6\% of Muslims in Indonesia who use Islamic banks for their transactions and investment. It showed that customers have low interest on Islamic bank. Objectives of this research were to analyze the influence of service quality of Islamic bank on customer satisfaction and trust. Survey on 130 respondents in the city of Makassar, Indonesia was conducted to collect information to explore the relationship between customer perception of the service quality of Islamic bank, satisfaction and trust. Accidental sampling was used to select the respondents with criteria of not an employee of the bank, have transaction of more than once per month and use more than one product and service of the Islamic banking. The Structural Equation Model (SEM) is used to analyze the direct and indirect relationship between Islamic bank service quality, satisfaction and trust. The findings of this research were that service quality of Islamic bank had significantly of influence on customers' satisfaction and then on their trust. Responsiveness of Islamic bank service was as the strongest attraction for customers to the Islamic bank. On the other hand, compliance was as the weakest attraction to the Islamic bank. Customers' satisfaction played an important role to support service quality of Islamic bank in influencing trust.
\end{abstract}

Keywords: Islamic bank, service quality, satisfaction, trust

\section{Introduction}

There are two banking systems in Indonesia, i.e. conventional banks with Islamic banks has a dual banking system, so that the customer can still make the choice between conventional banks with Islamic banks. National banking experience during the economic crisis of 1997-1999 is a valuable lesson. Muamalat bank of Indonesia, which was the pioneer of Islamic banking in Indonesia, it was not only survive but also able to increase net profit of $134 \%$ per year with an increase of $14 \%$ of their assets in 1999 when many other conventional banks collapsed during monetary crisis in 1997 (Anto \& Setyowati, 2008).

Legally and regulations, it appeared that the government has to provide enough space for the development of Islamic banking in Indonesia. Banking Act No. 10 of 1998 and No. 9 of 2008 as well as reinforced by the existence of Islamic banking in Indonesia, the development of Islamic bank showed progress by leaps and bounds. The world of banking in Indonesia began to establish Islamic unit or to change themselves into Islamic banking (Machmud \& Rukmana, 2010). By providing a wide range of banking products and services with various financial schemes, Islamic banking is to be a credible alternative for banking system and can be enjoyed by all Indonesian people without exception (Bank Indonesia, 2011).

In addition, the social function of Islamic bank is not only as supplementary nature of choice for Islamic banks, but also become a mandate of law No. 21 of 2008 about Islamic banking. According to article 4 paragraph (2) and (4) of law No. 21 of 2008 about Islamic banking, specific social-religious functions of Islamic bank, which is as a unique characteristic of Islamic bank must be as strong attraction for the community financial services or customer. These functions amplifies the role of Islamic banks, which are not only to become an institution of intermediary financing to business sectors but also help to facilitate efforts to increase the welfare of society, especially poorer people, who generally seek the service in the sector of micro-small or informal economy. 
Development of Islamic banking is still quite slow in respect of the time span since the Islamic bank (Muamalat Bank) was firstly established. In fact, the target of market share of 5 percent until the end of 2008 has been proclaimed Bank Indonesia threatened to fail (Kuncoro, 2008). Therefore, the main themes that are always to be hot topic for the offender of Islamic banking are how the right way to increase market share of Islamic banking. Current market contribution of Islamic banking was only around $2 \%$ of the total national banking (Ponggawa, Hanafiah \& Partner, 2009). Joyosumarto (2007, NU Online) revealed that only $1.6 \%$ of 176.88 million or about 1.71 million Muslims in Indonesia use Islamic banks for transactions and investments.

Hafasnuddin (2007) quoted by Arwani (2009) suggested that only 33.75\% of Islamic bank customers had true loyalty. The research identified that a factor that mostly affected customer loyalty to a bank is customer satisfaction (Akbar \& Parvez, 2009; Vesel \& Zabkar, 2009; Junisi, 2009; Chang \& Wang, 2011; Thakur \& Singh, 2012; Ltifi \& Gharbi, 2012). Omar et al. (2009) and Ramadania (2002) found no influence of customers' satisfaction against loyalty. Kantsperger and Kuntz (2010) reported that influence of customers' satisfaction against loyalty was mediated by trust. Only satisfaction is not enough to make someone loyal without being accompanied by trust.

Concept of trust was important in marketing during last decade (Kantsperger \& Kunz, 2010). Kantsperger and Kuntz (2010) developed a great conceptual model of customers' trust in service companies, namely benevolence and credibility, that is a very important aspect in creating loyalty and build a relationship up with customers. Being Graf and Perrine (2005) tested the role of trust and satisfaction in relation to hi-tech companies and bank in Europe and found the relationship between trust and satisfaction in constructing a sustainable relationship (Vlachos, Vrechopoulos \& Pramatari, 2010). Rhanu (2010) stated that customer satisfaction is the key to success in business services such as Islamic banking. The measurement of customer satisfaction is necessary to identify key success factors in the banking industry, while noting an increase in the size of the market and intense competition (Mengi, 2009).

Brady \& Robertson (2001) tested 2-way model between customer satisfaction and the quality of service and found that the antecedent of a customer satisfaction was service quality (Lee, Lee \& Yoo, 2000), not vice versa. Naeem, Akram \& Saif (2009) investigated customers' satisfaction as the impact of the quality of service on the banking sector and found that the quality of service was proved to be a strong predictor in terms of customer satisfaction. Other researchers, Yavas, Bankenstein \& Stuhldreier (2004) found that the quality of service was the root of customer satisfaction in retail bank in Germany. While Ting (2004) found that the quality of service was the antecedent of satisfaction in his research on Malaysia banking. So that, customer service was as an integral part of every facet of banking and determined the future of each banking organization (Mengi, 2009). Kotler (1997) stated that most of customers were no longer willing to accept and tolerate low quality service and performance of their bank partner.

Abdullah et al. (2011) who recently found a specific model of quality service of bank, i.e. service systems, responsive and reliability tested as an un-dimensional and suggested for further research to test in multidimensional. In addition, the customer's trust in the Islamic banking can be developed through adherence to Islamic banks on compliance which is the most important factor in the service quality of Islamic bank (Othman and Owen, 2001; Shafie, Azmi \& Haron, 2004; and Osman et al., 2009).

Therefore, this study aimed to explore the relationship between customer perception of the service quality of Islamic bank, satisfaction and trust. Specifically, this aims to find what customer's perception of the service quality of Islamic bank and ultimately it can drive customer satisfaction and customer trust.

\section{Literature Review}

This section highlights and review previous works related to resources, goals and approaches to the study of customer perceptions of Islamic bank service quality, satisfaction and ultimately on trust. For the purpose of this studied it is divided into three main groups, namely the study of customer trust, customer satisfaction and Islamic bank service quality.

\subsection{Customer Trust}

The concept of 'trust' is quite important in the field of marketing over the last decade and is seen as a key mediator of customer-oriented marketing. But after a closer look at the literature, building a 'trust' conceptualized and measured very differently. Based on the study of literature and theoretical works, this research is to develop a conceptual model of consumer confidence in the company's services primarily on Islamic banking industry.

Trust is an important concept in some field (Wang and Emurian, 2004) as social, sociology, economics, marketing, managements and information systems fields. Each discipline uses the definition so that there is no 
definition that can be universal accepted. The absence of a universal definition is due to the trust is an abstract concept and is often used interchangeably with credibility, reliability, or confidence and trust is a multi-faced concept, which combines the dimension of cognitive, emotional and behavior (Muawanah, 2010). Mayer et al. (1995) defines trust as the willingness of one party to be helpless (vulnerable) over the other parties. Hwang and Burgers (1977 in Mayer, Davis \& Schoorman, 1995) approved the trust as the probability of someone receiving cooperation behavior by other parties. Luhman (1979 in Mayer et al., 1995) consider trust as a belief by one party about another party that the party would behave in the way predicted, while the trust according to the Muawanah (2010) is a willingness to act on the basis of beliefs about the motives of other parties and the level of risk involved with action.

Sultan et al. (2002) gave a fascinating synthesis of the trust by showing that the trust has been part of all relationships. Trust the interdependence involves two or more parties. In Exchange, the interests of the parties involved requires dependence on each other. Trust implies a willingness to accept the vulnerability but with an expectation or belief that one can rely on the other party. In this case there is hope that other parties will behave like expected and did not exploit the vulnerability.

Trust as catalyst business relationship banks with its customers have been recognized by many sides, but still little evidence empiric being conclusive that supports strong correlation between trust customers by profitability in the company. Argument important can propose of these is trust customers will affect orientation long-term customers in business with a bank (Muawanah, 2010). Kantsperger and Kunz (2010) developed a conceptual model of consumer confidence in the company's services, which distinguishes two fundamental dimensions. The use of this dimension, it is possible to detect the effects of different mediation of trust in customer relations for service companies. The results of his research on the retail bank in favor of two dimensional model of trust. Furthermore, the two dimensions of trust that mediate the effects of different customer satisfaction. In particular, this showed that 'benevolence' have significant influence over customer loyalty rather than 'credibility', in addition to customer satisfaction, a tendency to trust the customers also affect trust. Aspects of benevolence are very important to create consumer loyalty and trust as well as build customer relationships. As a result, management should encourage activities that signal customers become good partners

\subsection{Customer Satisfaction}

Customer satisfaction is an important theoretical as well as practical problems for most consumer marketers and researchers (Dabholkar, Thorpe \& Rentz, 1996). Customer satisfaction can be considered as the core of success in a very competitive business world today. Thus, the importance of customer satisfaction in the development of a strategy to 'market-oriented' and 'customer focus' company could not be underestimated (Kohli and Jaworski, 1990). As a result, customer satisfaction has been the goal of the company as more and more companies are seeking to better quality in the products and services (Bitner \& Hubbert, 1994).

Many experts were given of definition of customer satisfaction. Tjiptono (2005) reveals that the satisfaction/dissatisfaction of the customer is the customer response to the evaluation of the perceived discrepancy/disconfirmation previous expectations and actual performance of a product that is felt after use.

The term of customer satisfaction were so popular and so very easily obtained in other literature and marketing literature, and have a very deep understanding so that it becomes a goal or goals to be achieve by the modern business organization it is today. The most common interpretation reflects the idea that satisfaction is a feeling that the result of the process of evaluating what is admissible against the expected, and/or purchasing decision itself or the fulfillment of needs/desires (Parker \& Mathews, 2001).

Engel, Blackwell \& Miniard (1995) stated that customer satisfaction as a full-time evaluation buy against the selected alternative that provides the same results or the surpass customer expectations. Kotler (2005) has defined as the degree of one's feelings after comparing performance results that he feels in comparison to his expectations. With the sense to see that there are two elements determine customer satisfaction, namely the performance of the services offered in conjunction with the expected performance, then users will feel sated. Thus customer satisfaction will be felt after consumers use services offered.

Customer satisfaction and service quality are often perceived equally, but in general the satisfaction is seen as a broader concept, while the assessment of the quality of services focused on the particular dimensions of the service. Thus, the quality of services that are perceives is one component of customer satisfaction (Zeithmal \& Bitner, 2000).

Many researchers operational customer satisfaction with using a single scale of dimensions and other researchers use several scale dimensions. Westbrook (1980) suggested that future researchers with 
multi-dimensional scale proposed for measuring customer satisfaction, what reduces measurement errors and increases the reliability of the scale at the same time. Sureshchandar, Rajenddran\& Anantharaman (2002) showed that customer satisfaction has to be seen as building a multi-dimensional and items of measurement should be made with the same service quality dimensions. His studies adopted a different approach and customer satisfaction is seen as multi-dimensional invalid constructs such as quality of service, and argues that customer satisfaction should be operational along the same factors in operational service quality.

\subsection{Islamic Bank Service Quality}

iB (read ai-Bi) abbreviation of Islamic Banking was popularized as a marker of identity of Islamic banking in Indonesia which was established since 2 July 2007. The use of this identity aims to keep the community quickly and easily recognize the availability of Islamic banking services in all over Indonesia, as modern society already familiar with the terminology-terminology iPhone, iPod or iBank. IB Logo is a marker of identity of the Islamic banking industry in Indonesia is the crystallization of the main values of Islamic banking system that is modern, transparent, equitable, balanced, and ethical that always puts the values of community and partnerships. The presence of the logo or term iB would make it easier for the public to recognize quickly and find an excess of Islamic banking services for the needs of their financial transactions.

Islamic Bank Service Quality (iBSQ) is the service quality of the Islamic banking in Indonesia that blends the iB terms above with the term BSQ (Bank Service Quality) was popularized by Petridou et al. (2006, 2007). Abdullah et al. (2011) to identify the quality of services for the banking sector, so that the term iBSQ is used to reflect the quality of service and Imaging for Islamic banking in Indonesia.

Islamic banking operations are derived from Islamic law and thus different in spirit, cultural background and practice of operation of conventional banks. Due to strong competition, expectations of customers to receive high quality service and rapid changes in technology, so that Islamic banks must think strategically by providing high-quality products and services to satisfy their customers. The main principle of Islamic financial institutions was interest-free is reflected in products generated.

In some countries, like the United Kingdom using the method mix, research Abdurrahim (2010) developed a model SERVQUAL was modified to measure the quality of service in the United Kingdom Islamic bank. The resulting instrument is intended to help managers Islamic banks based in the United Kingdom in order to measure the quality of their services and focus their attention on the dimension of the quality of service that are most important to Muslim customers. These instruments include thirty-four items, grouped into five dimensions. The five dimensions are responsiveness, credibility, accessibility, tangibles of Islamic and image bank.

In the United Arab Emirates, Jabnoun and Khalifa (2005) to develop the measurement of service quality on conventional bank and bank Islam and resulted in four dimensions of personal skills, reliability, value and image bank. Only the dimension values and personal skills are significant in determining the quality of services on Islamic banks.

In Kuwait, Othman and Owen (2001) suggests that it is important for the bank to place Islamic cultural differences when adopting the quality of service, and suggested a new model by incorporating elements of value to measure the quality of service. These measurements are called CARTER based on item 34. Study shows significant validity for all items CARTER and a strong link between quality of service and customer satisfaction. CARTER was Compliance, Assurance, Reliability, Tangible, Empathy, and Responsiveness.

In Malaysia, research Shafie et al. (2004) and Osman et al. (2009) only adopt research Othman and Owen (2001) in measuring the quality of the service of Islamic banks in Malaysia. Other research Abdullah et al. (2011) a measure of the quality of service on conventional banks and Islamic banks to adopt 34 items of the quality of service Parasuraman, Zeithaml \& Berry (1985). Their research give new instruments with 22 the item for the quality of a special service of banking industry which is the system of services, reliability and responsive.

In Indonesia, the service quality research on Islamic banking is largely adopted the quality service Parasuraman et al. (1988) as Ramadania (2002) at Bank Muamalat Indonesia in Surabaya, Fatmah (2007) in Islamic bank in East Java, Ciptono and Soviyanti (2007) in Islamic bank in Riau, Zahara (2007) in Islamic bank in Makassar.

IBSQ in this study combines research and adopt Othman and Owen (2001) were the first to introduce the Islamic compliance with the quality of service and research Abdullah et al. (2011) that designed the new measurement instruments in the banking sector and identify the 3-dimensional system service, responsiveness and reliability. But Abdullah et al. (2011) research on the banking sector in Malaysia is only the third such test uni-dimensions, reliability and validity with the analysis of factors without testing it with other variables such as customer satisfaction and trust. In addition, research cross culture, Kassim and Abdullah (2010) found that there 
was no difference between the influence of the quality of service to the customer satisfaction in two countries namely Qatar and Malaysia since the respondents have the same cultural background, so this research adopt Abdullah et al. (2011) because it has cultural similarities between the Malaysia and Indonesia.

\section{Methodology}

Sampling method in this study was accidental sampling, which meant taking samples or respondents based on coincidence, i.e., anyone who by chance met with investigators and met the criteria were selected and used as respondents. This technique is usually done due to lack of time, effort, and funds, so that, it is not possible to take a large size of sample. The advantage of this technique lies on the precision of the researchers in choosing data source that corresponds to the variables examined (Arikunto, 2002).

Criteria of respondents used in this research were that the respondents were not Islamic bank employees who enjoy services from the banking directly, Islamic bank customers who visit the bank at least once a month, and customers who use more than one products and services of the Islamic bank. A total of 130 customers were selected required and used as respondents. The number of respondents was calculated according to the techniques of Hair, et al. (2006) namely to obtain a sample that has a power that is assumed to be 0.8 alpha with researchers of $5 \%$.

The respondents were interviewed using structured questionnaire. All answers of question in the questionnaire were scaled into five points starting from strongly disagree to strongly agree according to Likert scale. The data were then descriptively analyzed using technical analysis approach inferential structural equation model (SEM).

\section{Results}

\subsection{Profiles of Respondent}

Profiles of respondent used in this research were age of $31-40$ years (31\%), female (54,6\%), highly educated/bachelor $(40 \%)$, married $(59,2 \%)$, have a business $(28,5 \%)$ and have income per month of RP. 5.000 .000 - RP. 10.000 .000 (40\%). Based on those compositions, profiles of the respondent were mostly housewife, having a business, and at productive age with moderate to high income. With those profiles, the respondents have a good financial condition for doing transactions with the bank (saving, withdrawing, lending (credit), and paying credit back).

Although most of respondents (43.6\%) stated that they were interested to be customer of Islamic bank was due to its products and services, but based on their bank account possession, most of the respondents (67.7\%) have also other accounts in conventional bank for their financial transactions in addition to their account in Islamic bank.

\subsection{SEM Analysis}

The validity and reliability of research instruments included variables (X1), responsive (X2), reliability (X3), Islamic Compliance (X4), Satisfaction (Y1) and trust (Y2). The results showed that values of each variable and correlation dimension was above 0.3 , meant that the overall variables and dimensions of the questions were valid. In addition, the six variables had value of alpha coefficients 0.60 which meant that the data instruments were valid and reliable.

Based on theoretical model on the conceptual framework of the study, the data must be fit if the data are supported by empirical data. Result of goodness of fit overall model using SEM analysis to determine whether hypothesis is supported by empirical data is presented in Figure 1 and Table 1. 


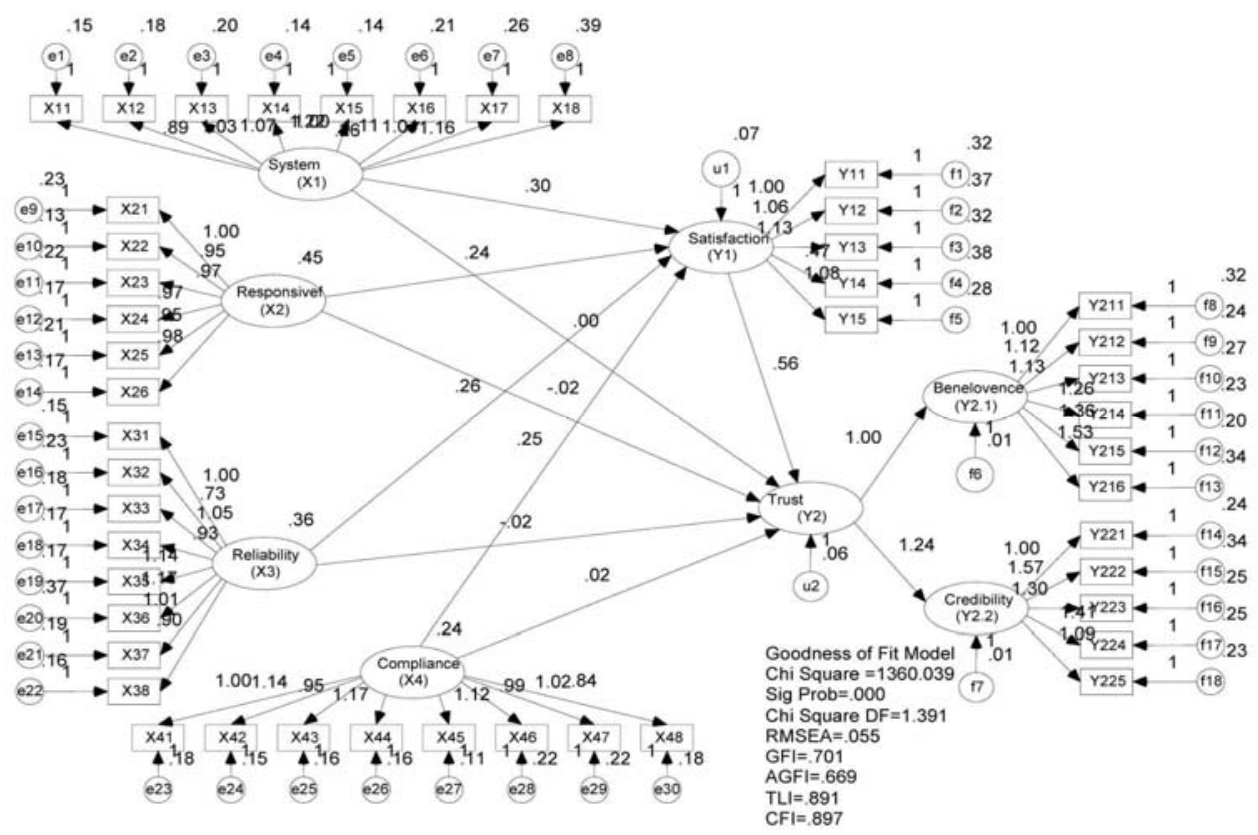

Figure 1. Output model of measurement using SEM analysis

Hypothesis testing was affected by the direct influence of the $t$ test ( $t$ test) in each of the direct influence of the partial path. Results of hypothesis testing of direct influence are presented in Table 1.

Based on direct influence above on path 4 of 9 are non-significant. It can be traced to the indirect effect. The indirect effect is obtained from the results of the second direct influence. If both direct influences are equally significant, then the indirect effect must also be significant. However, if one or both direct influences are not significant, then the indirect influence must also not be significant. Results of analysis of indirect influence are presented in Table 2.

Table 1. Direct influence hypotheses testing

\begin{tabular}{cccc}
\hline Independent variables & $\begin{array}{c}\text { Dependent } \\
\text { variables }\end{array}$ & Coefficient & p-value \\
\hline System (X1) & Satisfaction (Y1) & 0.390 & $0.001(\mathrm{~s})$ \\
Responsive (X2) & Satisfaction (Y1) & 0.401 & $0.001(\mathrm{~s})$ \\
Reliability (X3) & Satisfaction (Y1) & 0.389 & $0.001(\mathrm{~s})$ \\
Compliance (X4) & Satisfaction (Y1) & 0.319 & $0.001(\mathrm{~s})$ \\
System (X1) & Satisfaction (Y2) & -0.007 & 0.951 (ns) \\
Responsive (X2) & Trust (Y2) & -0.040 & 0.741 (ns) \\
Reliability (X3) & Trust (Y2) & -0.041 & $0.731(\mathrm{ns)}$ \\
Compliance (X4) & Trust (Y2) & 0.031 & $0.780(\mathrm{~ns})$ \\
Satisfaction (Y1) & Trust (Y2) & 0.688 & 0.005 (ns) \\
\hline
\end{tabular}

Note: s: significant, ns: non-significant. 
Table 2. Indirect influence hypotheses testing

\begin{tabular}{ccc}
\hline \multicolumn{1}{c}{ Independent, intervening and dependent variables } & \multicolumn{1}{c}{ Indirect } & p-value \\
\hline & $\mathrm{X} 1 \rightarrow \mathrm{Y} 1: 0.390(\mathrm{~s})$ & \\
$\mathrm{X} 1 \rightarrow \mathrm{Y} 1 \rightarrow \mathrm{Y} 2$ & $\mathrm{Y} 1 \rightarrow \mathrm{Y} 2: 0.688(\mathrm{~s})$ & Significant \\
& $0.390 \mathrm{x} 0.688=0.268$ & \\
$\mathrm{X} 2 \rightarrow \mathrm{Y} 1 \rightarrow \mathrm{Y} 2$ & $\mathrm{X} 2 \rightarrow \mathrm{Y} 1: 0.401(\mathrm{~s})$ & \\
& $\mathrm{Y} 1 \rightarrow \mathrm{Y} 2: 0.688(\mathrm{~s})$ & Significant \\
& $0.401 \mathrm{x} 0.688=0.279$ & \\
& $\mathrm{X} 3 \rightarrow \mathrm{Y} 1: 0.389(\mathrm{~s})$ & \\
$\mathrm{X} 3 \rightarrow \mathrm{Y} 1 \rightarrow \mathrm{Y} 2$ & $\mathrm{Y} 1 \rightarrow \mathrm{Y} 2: 0.688(\mathrm{~s})$ & Significant \\
& $0.389 \mathrm{x} 0.688=0.268$ & \\
& $\mathrm{X} 4 \rightarrow \mathrm{Y} 1: 0.319(\mathrm{~s})$ & \\
$\mathrm{X} 4 \rightarrow \mathrm{Y} 1 \rightarrow \mathrm{Y} 2$ & $\mathrm{Y} 1 \rightarrow \mathrm{Y} 2: 0.688(\mathrm{~s})$ & Significant \\
& $0.319 \mathrm{x} 0.688=0.219$ & \\
\hline
\end{tabular}

\section{Discussion}

\subsection{Service System to Customer Satisfaction}

The analysis it appears that there is strong evidence to claim that the presence of the influence of a significant and positive between the system of services to customer satisfaction. This is indicated that the better the system of services given Islamic banks will be able to increase customer satisfaction. So substantially to meet customer' satisfaction and prompt Islamic bank always improve the service system.

System is a systematic arrangement of services. Islamic banks need to pay attention to system of services, because it is one of the factors that make up their quality of service. System service will affect customer satisfaction. Service system in this research is reflected through eight indicators, including appropriateness of the service, service flexibility, simplicity of procedure, care and attention, the clarity of the standards, information technology, fulfilling the needs and affordability.

Results of the analysis showed that there was significant and positive influence of service system on customer's satisfaction. This indicated that better services provided by Islamic banking increased customer's satisfaction. In other word, customer satisfaction encouraged of Islamic banks to always improve their services for customers.

Empirically, previous researches had proven that system of service had influence or a positive relationship with the customer's satisfaction (Aldlagian \& Buttle, 2002; Sahadev \& Purani, 2008; Sadeh et al., 2011). The results of this research were in line with Fang et al. (2011) who reported that the system influenced significantly to quality of customer satisfaction. The better the service provided by the bank to the customer, the higher the customer's satisfaction on indicators of the system services. The most important contribution of indicators' to the system service was the concern and attention of the employees to the customers during transaction or in helping customers to solve problems. Care and attention of employees strongly influenced the system of services that ultimately increase customer satisfaction. Care and attention of employees was also due to that most of Islamic bank customers enjoyed the care and attention which facilitate the customer doing transactions, especially when first time open a account and make deposit, send money (money transfer), interbank transfers, withdrawing and saving money. In addition, respondents also enjoyed bonus in the form of points rewarded by the bank due to their debit or their use of credit card. In addition, the administrative fee and a low minimum balance are also able to increase customers' satisfaction.

\subsection{Responsive to Customer Satisfaction}

Responsive is a commitment of employees in giving service to customers. Based data analysis it was shown that there was significant and positive effect of responsiveness on customer satisfaction customer satisfaction. It means higher responsiveness of employees in serving customers will result in higher customer satisfaction.

The most important indicator in the responsive variable is the willingness of employee to give helps to customers. Willingness to help shown by the employees of Islamic banks is that customers have encountered in dealing, but this has not been done properly by Islamic bank in Makassar. Satisfaction responsive are still being under the level of satisfying. This condition decreased the competitiveness Islamic banks toward conventional banks. Willingness to help must be as a serious concern by Islamic bank, because this indicator is as the weakest 
ones among the overall responsiveness of employees to customers.

To anticipate bank employee disappointing the customer, bank employees improve continuously their responsiveness to what the customer needs, for example helping clients who are having trouble in filling form, directing the customers to the unit they needs, i quick handling customers' complaints and always consistent in the implementation of the service for the convenience of the customers.

This research was consistent with some earlier research (Parasuraman et al., 1985; Shafie et al., 2004) who reported that responsiveness was as the most variable that improved satisfaction for the customer. The results of this study were also in line with Ladhari et al. (2011) who found that the most important predictor of satisfaction was responsiveness, and Ribbink et al. (2004) who reported that responsiveness gave positive effect on customer satisfaction.

Variable responsiveness showed the most significant influence on customer satisfaction, this because due to the full attention and understanding personally and not regard social status of the bank to service the customers. Islamic bank employees did not hesitate to provide assistance to their customers. Islamic bank clients, especially those who have credit, do not need to come to the bank to pay the credit, but Islamic bank employees themselves who will go to the customer to collect the payment (picking ball up). Islamic bank clients feel that they have been given fully attention by the bank. This condition can increase customer satisfaction. Yeh and Li (2009) stated that responsiveness was very important not only as a measure of quality, but also as a diagnostic tool to reveal the service quality.

\subsection{Reliability to Customer Satisfaction}

Reliability meant the consistency of performance of the services. Based on data analysis, it was shown that there was a positively significant influence of the reliability on customer satisfaction. This indicated that higher consistency of service quality, increase customer satisfaction.

The most important indicator to develop reliability in this research was accurate information. This finding was evident because the clients who want to deposit their funds or to do other bank transactions wanted to have accurate information from the bank. This has not been very well done by Islamic bank. The customers will be satisfied when they are sure that bank employees who will serve them are reliable (precise and fast) especially giving accurate information and recording of customer account. So that, in providing fast, precise, accurate and satisfying services that has been promised need to be maintained and improved.

These results were supported by Abdullah et al. (2011), Jabnoun and Khalifa (2005), Parasuraman et al. (1985) who stated that the reliability affected customer satisfaction. In addition, Akbar and Parves (2009) reported that only variable reliability that gave significant effect on satisfaction of telecommunications customers' in Bangladesh. Ladhari et al. (2011) also reported that reliability was the the most variable giving significant effect on satisfaction customer in Canada and Tunisia bank. Abdullah et al. (2011) stated that to improve reliability required a good communication. It is services can be delivered to the customer with reliable, trustworthy and understandable manner.

\subsection{Compliance to Customer Satisfaction}

Compliance to Islamic is the hallmark of Islamic banking which describes the ability of the bank's compliance in applying the principles of Islam in any transactions, i.e., the bank operates in accordance with the principles of Islam, such as, without interest and producing Islamic products and services (share income, gharar, halal investment, zakat/charity, infaq, honest and fair).

From the results of the analysis to see that there is enough evidence to suggest that there is a significant and positive influence of Islamic compliance to customer satisfaction. This means that the better Islamic compliance applied to Islamic banking, will lead to increasingly higher levels of perceived satisfaction of the customer.

As research conducted by Othman and Owen (2001), Shafie et al. (2004), Osman et al. (2009), Lee and Ullah (2011) that customers really appreciated the compliance of Islamic bank and non-compliance with Islamic principles lead to dissatisfy customers. The most important indicator to develop compliance is free from uncertainty. This is evidenced by the contract is clear link between Islamic banks with customers in every banking transaction conducted by the subscribers that non-compliance with Islamic principles lead to dissatisfied, uncertainty regarding the final outcome of cooperation that can lead to disputes and litigation. So, free from uncertainty gives the sense that the possibility of a dispute or exploitation can be minimized. Unfortunately, this research indicated that compliance provided the lowest contribution for satisfaction compared to other variables. 


\subsection{System of Service to Trust}

The results of the analysis show that there is not enough strong evidence to suggest that there is a significant and positive influence of the system of service customer trust. This is indicated regardless of the value of the service, the system will have no effect on high low consumer trust. But there is an indirect effect of the system of service customer trust through customer satisfaction. That means the higher the service system, will lead to more and higher trust of the customer, if customer satisfaction also increased. Result of this research was certainly very interesting as previous researches reported that system of services had a significant influence on consumer trust (Sahadev and Purani, 2008; Sadeh et al., 2011).

Research by Sahadev and Purani (2008) on alumni and students who are seeking a job via internet suggests that the availability of system services affects customer trust. Sadeh et al. (2011) found the same results where availability of service system induced the trust of retailing company's customers in Iran. There was differences in application of service system in the previous research done by Sahadev and Purani (2008) and Sadeh et al. (2011) in this research done here. In the previous research, measurement system to assess the functionality of the service done website. While in this research, assessment of service system was performed by judging regularly and system delivery of bank services to customers. The difference of research results was due to the role of mediation on customer satisfaction, where in the researches of Sahadev and Purani (2008) and Sadeh et al. (2011) those variables could directly affect customer trust.

The customer cannot be said to believe or trust the system services provided by Islamic banks if it did not give customer satisfaction. Gounaris and Venetis (2002) revealed that not all dimensions of service quality gave the same contribution to the trust. The success of the service system requires quite a long time in improving trust. The element of time was very instrumental in developing long term relationships. It is well known that Islamic commercial banks in Indonesia were just recent established within the 35 years, thus some respondents were not long to be Islamic bank customer.

In addition, there was some complain from customer, for example respondents also complained about the parking is narrow and the availability of the number of ATM causes respondents are not so sure of system services provided by the bank. Some Islamic banks did not provide facilities such as TV, newspapers, or magazines and a queue screen number in the waiting room. The waiting room was cramped and unsanitary. These all conditions might weaken the influence of service system on customer trust. It was also found that availability of information technology is not yet capable of Islamic banks to help improve customer businesses.

\subsection{Responsive to Trust}

The results of the analysis to see that there is not yet enough evidence stated that there is a significant and positive influence of responsive to customer trust. This is indicated regardless of the value of responsive, will have no effect on high low consumer trust. However, there are indirect influences between responsive to customer trust through customer satisfaction. That means the higher the responsive, will lead to more and higher trust of the customer, if customer satisfaction is also increasing.

Data of this research was different from research done by Al-Hawari (2011) who reported positive influence of responsive to trust on the context of retail banks in the UAE. In addition, Akbar and Parvez (2005) in the case of Grameen Phone in Bangladesh found only a dimension of responsiveness to customers that affect their trust. Yeh and Li (2009) also found the influence of responsive to customer trust. However, result of this research was in line with Ribbink et al. (2004) on student as user of online book and CD shop, who reported that there was no positive effect of responsive on customer trust.

The result indicated that the employee's skills, willingness to help, priority on customer satisfaction, behavior, courtesy, friendliness and knowledge of employees were not enough to improve customer trust if the customer had not been satisfy with responsiveness of the bank employees. The employee of Islamic bank in Makassar had not shown consistency in helping and responding to customer's requests, especially if clients found difficulty in filling forms, failure in banking transactions, withdrawals and other services. In addition, the willingness to help by bank employees did not improve customer trust.

This was possibly because of the customers were still not too long to be a customer and felt the consistency of responsiveness of the bank. Customers still felt that the customer services were a bit slow, especially when using one of the new Islamic banking products or when replacing full book account. The time delay is also a bit long so long queue still common. And respondent still finds tellers and security guards are not friendly.

Abdullah et al. (2011) suggested the importance of employees' behavior, such as pleasant, courteous and friendly service to develop trust among customers. 


\subsection{Reliability of Trust}

The analysis has seen that there is strong evidence to claim that the significant positive influence and reliability of trust among customers. It indicated reliability irrespective of that value will have no effect on high low trust customers. But there is no direct influence between responsive to trust customers via customer satisfaction. Higher, dependability means will result in higher trust, and customers if customer satisfaction, also increase.

Result of this research was different from research of Yee et al. (2005) who found antecedents trust was reliability of their research on livestock farmers in the United Kingdom. However result of this study supported research done by Yee et al. (2005) and Gill et al. (2006), who reported that consumer trust was not affected by reliability characteristics of insurance and bank services. Gill et al., (2006) also found that the reliability was failure to be the antecedent of trust in service characteristics associated with the company's business.

In this study, the bank guarantee in providing accurate information to the customer could be an important indicator for reliability. The most dominant indicator that improves trust was the ability of banks in providing advices to the customer. Result of this research that showed not significant effect of reliability on customer trust could happen because of the bank often gave not accurate information in providing advice to the customer.

The results of this study also found that some customers still complained about the procedure of the Hajj and calculation of share income which were not clear, and sometimes customer service did not explain accurately and completely when there was a problem. In addition, service system used was often slow and sometimes unreliable. This happened especially in the case of interbank transfer process, which took quite long time and even often fail and required quite high transfer fee. Respondents also often found ATM machines that were empty or damaged especially during long holiday. ATM cash transfer via ATM that often did not work. There was no security guard near ATM machine. These all conditions made the customers not sure for the bank services. In addition, it was found that facilities provided by the bank have not been able to help customers in their business.

Yee et al. (2005) emphasized that reliability could improve consumer trust if the company was able to provide accurate information, shows their virtues and credibility to the customers which in turn would affect positively to consumer purchasing decisions.

\subsection{Compliance to Trust}

The result analysis seen that is yet there's enough evidence to suggest that the presence of the influence of the influence of a significant and positive between adherence to trust customers. It indicates that irrespective of that value compliance will have no effect on high low-self trust customers. But there is indirect effect between compliance customers via customer satisfaction of faith. This means that getting high compliance will result in higher trust and customers if customer satisfaction also increases.

Specific characters of Islamic bank that might facilitate consumer trust are related to the operations of the bank based on the principles of Islam. The bank produces Islamic products and services such as offering investment with no bank interest but with income sharing instead, investment for hajj and umrah. Allowance of a portion of the profits for charity and alms, and transactions are done honestly and fair.

Lack of customer trust on the compliance of Islamic bank on the principles of Islam was due to lack of information received by customers, especially about the management of their funds in accordance with the principles of Islam. This was especially related to bank interest and income sharing system, and also distribution of credits for business which were contrary to the principles of Islam. Respondents strongly considered uncertain (gharar) transactions carried out by the bank. Unfortunately, the absence of bank interest given by the bank had not been able to improve customers of business.

It is not easy to get customer trust, especially for Islamic banks that are operated based on the principles of Islam. The customer trust is not possible to be achieved in a short period of time. The trust will grow with time after the customers evaluate bank operation and services for a long period of time. These findings indicated also that there was still doubt on the consistency of Islamic bank operation and services according to the principles of Islam. Separation of male and female customer services which was not practiced by the bank and also clothing for female customer services which were too tight (snugly) influenced the consumer trust on the compliance of Islamic bank on the principles of Islam.

Duncan (2004) as quoted by Zahara (2007) suggested that high customer trust due to good service and its consistency showed how important the best services given by bank for their customer trust. 


\subsection{Satisfaction to Trust}

This research found a positive and significant influence of satisfaction on trust. This showed that the bank got trust from the customer through the fulfillment of customer satisfaction. Kassim and Abdullah (2010) and Omar et al. (2009) reported that customer satisfaction become an important factor in building customer trust. Kotler (1997) confirms that trust is a very important thing, especially for companies dealing with services.

However, these results were different from those reported by Ramadania (2002) at Muamalat bank of Surabaya that customer satisfaction did not have an impact on trust.

By providing a consistent and sincere services will give satisfaction to customers. The customers were satisfied not only by the honest, fairness, and free from uncertainty of Islamic banks, but also they felt to be able to practice the principles of Islam in doing banking transactions. In addition, customer trust arises because Islamic banks were able to meet the customer needs, help their business and solve financial problems. Therefore, bank management must always be consistent in providing the best services to their customers. Aiyub (2007) recommended that the bank must maintained people who are already willing to join and become a customer of Islamic bank by giving good bank image through best services and highly professional work.

\subsection{Limitation}

The time factor holds an important role in developing customer trust. In this study, the length of the relationship between customer and Islamic bank was not examined. This was because several Islamic banks were recently established in Makassar Indonesia.

Gronouis and Venetis (2002) found that the quality of service will affect the trust of customers if the service provider has long been associated (length of the relationship) to the customer. Length of the relationship between variables is moderation the quality of service and trust in the research of Graf and Perrien (2005) and Coulter and Coulter (2002).

\section{Conclusion}

Service quality of Islamic bank increased customer trust through the mediation of customer satisfaction. Employees' care and willingness to help (responsiveness), accurate information and free of uncertainty were as the most important factors in providing quality of service by Islamic banks to their customer satisfaction and trust. However, compliance to the principles of Islam including social function, which are the unique of Islamic bank was as the lowest factor for customer satisfaction and trust. In addition, customer satisfaction and trust on Islamic bank were likely developed by the credibility of the bank. To be customer of Islamic bank, respondents still considered first economic aspect rather than emotional or spiritual aspect.

\section{References}

Abdullah, F., Suhaimi, R., Saban, G., \& Hamali, J. (2011). Bank Service Quality (BSQ) Index: An Indicator of Service Performance. International Journal of Quality \& Reliability Management, 28(5), 542-555. http://dx.doi.org/10.1108/02656711111132571

Abdurrahim, N. (2010). Service Quality of English Islamic Bank. Bournemouth University, United Kingdom.

Aiyub. (2007). Analisis Perilaku Masyarakat terhadap Keinginan menabung and Memperoleh Pembiayaan pada Bank Islamic di Nanggroe Aceh Darussalam. Jurnal E-Mabis FE-Unimal, 8(1), 1-17.

Akbar, M. M., \& Parvez, N. (2009). Impact of Service Quality, Trust, and Customer satisfaction on Customer Loyalty. ABAC Journal, 29(1), 24-38.

Aldlaigan, A. H., \& Buttle, F. A. (2002). Systra-SQ: a New Measure of Bank Service Quality. International Journal of Service Industry Management, 14(4), 362-381. http://dx.doi.org/10.1108/09564230210445041

Al-Hawari, M. A. (2011). Automated Service Quality As A Predictor Of Customers' Commitment: A Practical Study Within The UAE Retail Banking Context. Asia Pacific Journal of Marketing and Logistics, 23(3), 346-366. http://dx.doi.org/10.1108/13555851111143259

Anto, \& Setyowati. (2008). Indikasi Moral Hazard Penyaluran Dana Pihak Ketiga pada Bank Konvensional and Islamic bank di Indonesia. Jurnal Keuangan and Perbankan.

Arikunto, S. (2002). Prosedur Penelitian Suatu Pendekatan Praktek. Rineka Cipta: Jakarta.

Arwani, M. (2009). Peran Moderator Karakteristik Individ: Pengaruh Kepuasan and Relationship Marketing terhadap Loyalitas. Studi Empiris pada Nasabah Islamic bank di Jawa Timur, Disertasi PPs FE UB.

Bank Indonesia. (2011). Laporan Perkembangan Perbankan Islamic 2010. Direktorat Perbankan Islamic Bank 
Indonesia.

Bitner, M. J., \& Hubbert, A. R. (1994). Encounter Satisfaction versus Overall Satisfaction versus Quality. In R. T. Rust \& R. L. Oliver (Eds.), Service Quality: New Directions (pp. 72-94). Thousand Oaks, Sage Publications, California.

Brady, M. K., \& Robertson, C. J. (2001). Searching For A Consensus on The Antecedent Role of Service Quality and Satisfaction: An Exploratory Cross-National Study. Journal of Business Research, 51, 53-60. http://dx.doi.org/10.1016/S0148-2963(99)00041-7

Chang, S. S., \& Wang, S. W. (2011). The Moderating Effect of Customer Perceived Value on Online Shopping Behaviour. Online Information Review, 35(3), 333-359. http://dx.doi.org/10.1108/14684521111151414

Ciptono, W. S., \& Soviyanti, E. (2007). Adapting Islamic Bank’s Carter Model: An Empirical Study in Riau’s Syariah Banks, Indonesia. Proceeding PESAT (Psikologi, Ekonomi, Sastra, Arsitek, Sipil). Auditorium Kampus Gunadarma: Jakarta.

Coulter, K. S., \& Coulter, R. A. (2002). Determinants Of Trust In A Service Provider: The Moderating Role Of Length Of Relationship. Journal of Services Marketing, 16(1), 35-50. http://dx.doi.org/10.1108/08876040210419406

Dabholkar, P. A., Thorpe, D. I., \& Rentz, J. O. (1996). A Measure of Service Quality for retail Stores: Scale Development and validitation. Journal of the Academy of Marketing Science, 24(1), 3-16. http://dx.doi.org/10.1007/BF02893933

Engel, J. F., Blackwell, R. D., \& Miniard, P. W. (1995). Perilaku Konsumen, Jilid 1. Alih Bahasa: F.X Budiyanto. Binarupa Aksara Publisher: Tangerang.

Fang, Y. H., Chiu, C. M., \& Wang, E. T. G. (2011). Understanding Customers' Satisfaction and Repurchase Intentions: An Integration of IS Success Model, Trust and Justice. Internet Research, 21(4), 479-503. http://dx.doi.org/10.1108/10662241111158335

Gill, A. S., Flaschner, A. B., \& Shachar, M. (2006). Factors That Affect the Trust Of Business Clients In Their Banks. International Journal of Bank Marketing, 24(6), 384-405. http://dx.doi.org/10.1108/02652320610701726

Gounaris, S. P., \& Venetis, K. (2002). Trust in Industrial Service Relationships: Behavioral Consequences, Antecedents and Moderating Effect of The Duration of The Relationship. Journal of Service Marketing, 16(7), 636-655. http://dx.doi.org/10.1108/08876040210447351

Graf, R., \& Perrien, J. (2005). The Role of Trust and Satisfaction in A Relationship: The Case of High Tech Firm and Banks. Paper Presented at the 2005 Conference of the European Marketing Academy (EMAC).

Hair, J. F., Black, W. C., Babin, B. J., Andersen, R. O., \& Tatham, R. L. (2006). Multivariate Data Analysis. New York: Pearson Prentice Hall.

Jabnoun, N., \& Khalifa, A. (2005). A Customized Measure Of Service Quality In The UAE. Managing Service Quality, 15(4), 374-388. http://dx.doi.org/10.1108/09604520510606844

Joyosumarto, A. S. (2007). Hanya 1,71 Juta Umat Islam Indonesia Pakai Islamic bank. Retrieved from hattp://www.nu.or.id

Junisi, R. E. (2009). Pengaruh Atribut Produk Islam, Komitmen Agama, Kualitas Jasa and Kepercayaan Terhadap Kepuasan and Loyalitas Nasabah Bank Syari’ah (Pada Bank Muamalat Kota Semarang). The 9th Annual Conference on Islamic Studies (ACIS), Surakarta.

Kantsperger, R., \& Kunz, W. H. (2010). Consumer Trust In Service Companies: A Multiple Mediating Analysis. Managing Service Quality, 20(1), 4-25. http://dx.doi.org/10.1108/09604521011011603

Kassim, N., \& Abdullah, N. A. (2010). The Effect of Perceived Service Quality Dimensions on Customer Satisfaction, Trust, and Loyalty. In E-Commerce Settings: A Cross Cultural Analysis. Asia Pacific Journal of Marketing and Logistics, 22(3), 351-371. http://dx.doi.org/10.1108/13555851011062269

Kotler, P. (1997). Marketing Management. New Jersey: Prentice-Hall.

Kotler, P. (2005). Manajemen Pemasaran. Jakarta: Indeks Kelompok Gramedia.

Kohli A. K., \& Jaworski, B. J. (1990). Market Orientation: The Construct, Research Propositions, and Managerial Implications. Journal of Marketing, 54(2), 1-18. http://dx.doi.org/10.2307/1251866 
Kuncoro, Y. (2008). Langkah Strategis Meningkatkan Pangsa Pasar Perbankan Islamic. Sinar Harapan edisi Selasa.

Ladhari, R., Ladhari, I., \& Morales, M. (2011). Bank Service Quality: Comparing Canadian and Tunisian Customer Perceptions. International Journal of Bank Marketing, 29(3), 224-246. http://dx.doi.org/10.1108/02652321111117502

Lee, H., Lee, Y., \& Yoo, D. (2000). The Determinants of Perceived Service Quality and Its Relationship with Satisfaction. Journal of Services Marketing, 4(3), 217-231. http://dx.doi.org/10.1108/08876040010327220

Lee, K. H., \& Ullah, S. (2011). Customers’ Attitude Toward Islamic Banking In Pakistan. International Journal of Islamic and Middle Eastern Finance and Management, 4(2), 131-145. http://dx.doi.org/10.1108/17538391111144524

Ltifi, M., \& Gharbie, J. E. (2012). Satisfaction and Loyalty with the Tunisian Postal Service. International Journal of Humanities and Social Science, 2(7), 178-191.

Machmud, A., \& Rukmana, H. (2010). Islamic bank: Teori, Kebijakan, and Studi Empiris di. Indonesia, Jakarta: Penerbit Erlangga.

Mayer, R. C., Davis, J., \& Schoorman, F. D. (1995). An Integrative Model of Organizational Trust. Academy of Management Review, 91-106.

Mengi, P. (2009). Customer satisfaction with Service Quality: An Empirical Study of Public and Private Sector Banks. Institute of Chartered Financial Analysts of India (Hyderabad). The ICFAI Journal of Management Research, 8(9), 7-18.

Muawanah, U. (2010). Praktik Corporate Governance and spritual Islami di Perbankan Islamic: Pendekatan Mixed Method. Disertai PDIA PPSFEUB.

Naeem, H., Akram, A., \& Saif, M. I. (2009). Service quality and its Impact on Customer satisfaction: An Empirical Evidence From the Pakistani Banking Sector. International Business \& Economics Research Journal, 8(12), 99-105.

Omar, N. A., Nazri, M. A., Abu, N. K., \& Omar, Z. (2009). Parents’ Perceived Service Quality, Satisfaction and Trust of a Childcare Centre: Implication on Loyalty. International Review of Business Research Papers, 5(5), 299-314.

Osman, I., Ali, H., Zainuddin, A., \& Rashid, W. E. W. (2009). Customer satisfaction in Malaysian Islamic Banking. International Journal of Economic and Finance, 1(1), 197-202.

Othman, A., \& Owen, L. (2001). Adopting and Measuring Customer Service Quality (Sq) In Islamic Banks: A Case Study In Kuwait Finance House. International Journal of Islamic Financial Services, 3(1), 1-26.

Parasuraman, A., Zeithaml, W., \& Berry, L. (1985). A Conceptual Model of Service Quality and its Implications for Future Research. Journal of Marketing, 49, 41-50. http://dx.doi.org/10.2307/1251430

Parasuraman, A., Zeithaml, W., \& Berry, L. (1988). SERVQUAL: a Multiple Item Scale for Measuring Consumer Perceptions of Service Quality. Journal of Retailing, 64(1), 2-40.

Parker, C., \& Mathews, B. P. (2001). Customer satisfaction: Contrasting Academic and Consumers' $\begin{array}{lllll}\text { Interpretations. Marketing Intelligence \& } & \text { Planning, } & \text { 19(1), }\end{array}$ http://dx.doi.org/10.1108/02634500110363790

Petridou, E., Glaveli, N., Liassides, C., \& Spathis, C. (2006). Bank Service Quality: Evidence From five Balkan Countries. Managing Service Quality, 16(4), 380-394. http://dx.doi.org/10.1108/09604520610675711

Petridou, E., Glaveli, N., Liassides, C., \& Spathis, C. (2007). Bank Service Quality: Empirical Evidence From Greek And Bulgarian Retail Customers. International Journal of Quality \& Reliability Management, 24(6), 568-585. http://dx.doi.org/10.1108/02656710710757772

Ponggawa, H., \& Partner. (2009). Pengumuman atas Ringkasan Pemisahan Unit Usaha Islamic PT Bank Negara Indonesia (Persero) Tbk Dengan Cara Pendirian Bank Umum Islamic. Jakarta: Media BNI. Terbit 12 Juli 2009.

Ramadania. (2002). Kepercayaan and Komitmen Sebagai Perantara Kunci Relationship Marketing Dalam Membangun Loyalitas (Survei Pada Nasabah Bank Muamalat Indonesia Surabaya). Jurnal Riset Ekonomi and Manajemen, 2(1), 33-52.

Rhanu. (2010). Tantangan dalam Pengembangan Perbankan Islamic di Indonesia. Gunadarma. 
Ribbink, D., Allard, V. L. C. R., Veroniva, L., \& Sandra, S. (2004). Comfort Your Online Customer: Quality, Trust, and Loyalty on the Internet. Managing Service Quality, 14(6), 446-456. http://dx.doi.org/10.1108/09604520410569784

Sadeh, E., Mousavi, L., Garkaz, M., \& Sadeh, S. (2011). The Structural Model of E-Service Quality, E-Customer Satsifaction, Trust, Customer Perceived Value and E-Loyalty. Australian Journal of basic and Applied Sciences, 5(3), 532-538.

Sahadev, S., \& Purani, K. (2008). Modelling the Consequences of E-Service Quality. Marketing Intelligence \& Planning, 26(2), 605-620. http://dx.doi.org/10.1108/09604520410569784

Shafie, S., Azmi, W. N. W., \& Haron, S. (2004). Adopting And Measuring Customer Service Quality In Islamic Banks: A Case Study Of Bank Islam Malaysia Berhad. Journal of Muamalat and Islamic Finance Research, 1(1), 1-12.

Sugiyono. (2004). Statistika Untuk Penelitian. Cetakan Ketiga. CV. Alfabeta: Bandung.

Sultan, F., Glen, l. U., Venkatesh, S., \& Iakov, Y. B. (2002). Determinant and Role of Trust in E-Bussiness: A Large Scale Empirical Study. Working Paper 4282-02, MIT Sloan School of Management.

Sureshchandar, G. S., Rajenddran, C., \& Anantharaman, R. N. (2002). The Relationship between Service Quality and Customer satisfaction: a Factor Spesific Approach. Journal of Service Marketing, 16(4), 363-379. http://dx.doi.org/10.1108/08876040210433248

Thakur, S., \& Singh, D. R. A. (2012). Brand Image, Customer satisfaction and Loyalty Intention: Study in The Context of Cosmetic Product among of The People of Central India. EXCEL International Journal of Multidisciplinary Management Studies, 2(5), 37-50.

Ting, D. H. (2004). Service Quality and Satisfaction Perceptions: Curvilinear and Interaction Effect. The International Journal of Bank Marketing, 22(6), 407-420. http://dx.doi.org/10.1108/02652320410559330

Tjiptono, F. (2005). Pemasaran Jasa, Edisi Pertama, Cetakan Pertama. Malang: BayuMedia Publishing.

Vesel, P., \& Zabkar, V. (2009). Managing Customer Loyalty trough The Mediating Role of Satisfaction in the DIY Retail Loyalty Program. Journal of Retailing and Customer Service, 16, 396-406. http://dx.doi.org/10.1016/j.jretconser.2009.05.002

Vlachos, P. A., Vrechopoulos, A. P., \& Pramatari, K. (2011). Too Much Of A Good Thing: Curvilinear Effects In The Evaluation Of Services And The Mediating Role Of Trust. Journal of Services Marketing, 25(6), 440-450. http://dx.doi.org/10.1108/08876041111161032

Wang, Y. D., \& Emurian, H. H. (2004). An Overview of Online Trust: Concept, Element, and Implications. Computers in Human Behavior, 21, 105-125. http://dx.doi.org/10.1016/j.chb.2003.11.008

Westbrook, R. A. (1980). A Rating Scale for Measuring Product/Service satisfaction. Journal of Marketing, 44(4), 68-72. http://dx.doi.org/10.2307/1251232

Yavas, U., Bankenstein, M., \& Stuhldreier, U. (2004). Relationships Between Service Quality and Behavioral Outcomes. The International Journal of Bank Marketing, 22(2), 144-157. http://dx.doi.org/10.1108/02652320410521737

Yee, W. M. S., Yeung, R. M. W., \& Morris, J. (2005). Food Safety: Building Consumer Trust In Livestock Farmers For Potential Purchase Behavior. British Food Journal, 107(11), 841-854. http://dx.doi.org/10.1108/00070700510629788

Yeh, Y. S., \& Li, Y. M. (2009). Building Trust in M-Commerce: Contributions from Quality and Satisfaction. Online Information Review, 33(6), 1066-1086. http://dx.doi.org/10.1108/14684520911011016

Zahara, Z. (2007). Peran Kualitas Layanan Terhadap Kepuasan, Kepercayaan, Komitmen and Loyalitas Nasabah dalam Hubungan Kemitraan. Disertasi PPs FE UB.

Zeithmal, V. A., \& Bitner, M. J. (2000). Services Marketing: Integrating Customers Focus Across the Firm (2nd ed.). Irwin McGraw-Hill: Boston. 